\title{
PENGARUH MODEL PEMBELAJARAN PROCESS ORIENTED GUIDED INQUIRY LEARNING TERHADAP KEMAMPUAN ANALOGI MATEMATIS PESERTA DIDIK
}

\author{
Fauzia Hajar Hasanah"1), Sigid Edy Purwanto'), Ayu Tsurayya ${ }^{3)}$ \\ 1)Universitas Muhammadiyah Prof.DR.Hamka, Jln. Tanah Merdeka No. 20, Jakarta Timur; \\ fauziahajar@gmail.com \\ 2) Universitas Muhammadiyah Prof.DR.Hamka, Jln. Tanah Merdeka No. 20, Jakarta Timur; \\ sigid@uhamka.ac.id \\ 3) Universitas Muhammadiyah Prof.DR.Hamka, Jln. Tanah Merdeka No. 20, Jakarta Timur; \\ ayu.tsurayya@uhamka.ac.id
}

\begin{abstract}
This study aims to examine and produce a study of the influence of the Process Oriented Guided Inquiry Learning learning model on the Mathematical Analogy Capabilities of students in SMP Negeri 2 Rangkasbitung in class VIII of the 2018/2019 school year on the material solid geometry with plane side. The research method used is Quasi Experiment with research design The Nonequivalent PosttestOnly Control Group Design. The sampling technique used is Cluster Random Sampling. The results of the study stated that the learning model Process Oriented Guided Inquiry Learning affects the mathematical ability of mathematical students. The influence of the model is classified on the medium criteria, with an Effect Size of 0.4660 .
\end{abstract}

Keywords. Mathematical analogy ability, Process Oriented Guided Inquiry Learning model

\section{Pendahuluan}

\subsection{Latar Belakang Masalah}

Matematika merupakan suatu ilmu yang memiliki peran sangat penting dalam kehidupan terutama dalam bidang pendidikan. Matematika digunakan dalam kehidupan sehari-hari seperti dalam perdagangan dan teknologi. Banyak ilmu-ilmu yang pengembangannya berasal dari matematika. Sebagai faktanya, pada kurikulum yang berlaku dalam sistem pendidikan di Indonesia mata pelajaran matematika mendapat porsi yang lebih banyak dibandingkan dengan mata pelajaran lainnya di sekolah. Matematika adalah suatu mata pelajaran yang dapat membantu peserta 
didik mempersiapkan dirinya dalam menghadapi dan memecahkan masalah. Hal ini didukung oleh National Council of Teachers of Mathematics (NCTM) tahun 2000 (Rosidah, 2013) dengan menetapkan lima komponen Principles and Standars for School Mathematics yaitu: komunikasi matematika (mathematical communication), penalaran matematika (mathematical reasoning), pemecahan masalah matematika (mathematical problem solving), koneksi matematika (mathematical connections), representasi matematika (mathematical representation).

Meskipun demikian, proses pembelajaran matematika yang berlangsung di Indonesia kebanyakan masih berorientasi pada penguasaan keterampilan dasar, hanya sedikit sekali penekanan penerapan emosional spiritual dalam pembelajaran dan kemampuan bernalar. Melihat fakta-fakta yang masih jauh dari harapan, sebagai calon pendidik tentu harus melakukan upaya-upaya untuk memperbaiki sistem pembelajaran matematika di Indonesia yang masih belum optimal. Dalam pembelajaran matematika, peserta didik diharapkan mampu memahami konsep-konsep matematika. Namun pada saat ini masih banyak peserta didik yang belum mampu memahami konsep matematika dengan baik. Hal ini dikarenakan sebagian besar konsep matematika merupakan konsep abstrak yang sulit dipahami oleh peserta didik sehingga diperlukan suatu kemamapuan matematis yang dapat membantu peserta didik dalam memahami konsep-konsep matematika. Salah satu kemampuan matematis yang dapat menggambarkan suatu konsep abstrak menjadi konkrit adalah kemampuan analogi matematis.

Permasalahan yang diberikan dalam analogi yaitu adanya keserupaan konsep diantara dua masalah, yaitu masalah sumber dan masalah target (Rahmawati \& Pala, 2017). Dengan adanya keserupaan konsep atau proses tersebut maka akan memudahkan peserta didik untuk menyelesaikan permasalahan tersebut. Selain itu, kemampuan analogi matematis membantu peserta didik dalam memahami konsep-konsep matematika, salah satunya konsep-konsep abstrak. Hal ini dikarenakan melalui kemampuan analogi matematis, peserta didik dapat menggambarkan suatu konsep abstrak menjadi konkrit. Peran analogi secara khusus dalam pembelajaran matematika menurut Isoda \& Katagiri (Azmi, 2017) adalah untuk membentuk perspektif dan menemukan pemecahan masalah. Artinya 
analogi merupakan salah satu alat yang dapat digunakan peserta didik dalam memecahkan masalah matematika dalam pembelajaran matematika. Pemilihan model pembelajaran yang tepat dalam proses pembelajaran matematika akan berpengaruh terhadap minat serta kemampuan peserta didik dalam menyelesaikan masalah matematika.

\section{Metodologi Penelitian}

\subsection{Metode Penelitian}

Metode penelitian ini adalah Quasi Eksperimen dan desain yang digunakan adalah The Nonequivalent Posttest-Only Control Group Design (Lestari \& Yudhanegara, 2015). Dalam penilitian ini ada dua kelas yang diberikan perlakuan berbeda yaitu kelas eksperimen yang diajarkan dengan model pembelajaran Process Oriented Guided Inquiry Learning dan kelas kontrol yang tidak diajarkan dengan model pembelajaran Process Oriented Guided Inquiry Learning, setelah diberikan perlakuan kedua kelas diberikan posttest untuk mengukur kemampuan analogi matematis peserta didik. Adapun desain penelitian yang digunakan sebagai berikut:

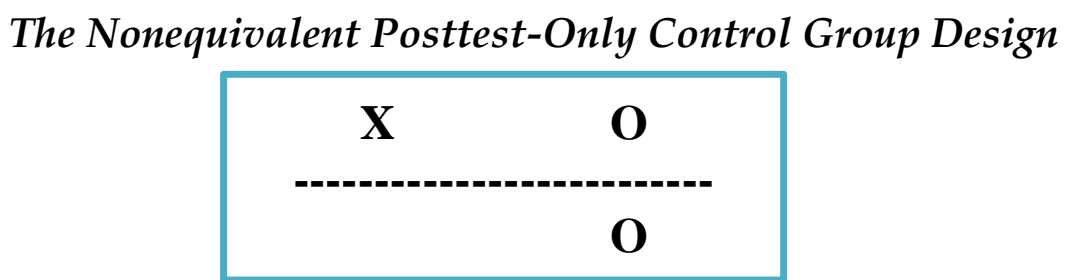

Gambar 1. Desain Penelitian

Keterangan:

X : Perlakuan pada kelas eksperimen dengan model pembelajaran Process Oriented Guided Inquiry Learning

$\mathrm{O} \quad$ : Posttest Kemampuan Analogi Matematis

\subsection{Populasi dan Sampel}

Populasi adalah wilayah generalisasi yang terdiri atas: obyek/subyek yang mempunyai kualitas dan karakteristik tertentu yang ditetapkan oleh peneliti untuk dipelajari dan kemudian ditarik kesimpulannya (Sugiyono, 2014). Populasi dalam penelitian ini adalah seluruh peserta didik kelas VIII SMP Negeri 2 Rangkasbitung yang terdaftar pada semester genap tahun ajaran 2018/2019. Sampel adalah bagian dari jumlah dan karakteristik yang dimiliki 
oleh populasi (Sugiyono, 2014). Teknik pengambilan sampel dalam penelitian ini dilakukan dengan teknik Cluster Random Sampling. Setelah pengocokan dan pengambilan gulungan kertas, terpilih dua kelas yaitu kelas VIII-A sebagai kelas eksperimen yang diajarkan dengan model pembelajaran Process Oriented Guided Inquiry Learning dan kelas VIII-B sebagai kelas kontrol yang tidak diajarkan dengan model pembelajaran Process Oriented Guided Inquiry Learning. Sampel dalam penelitian ini adalah kelas VIII-A dan VIII-B di SMP Negeri 2 Rangkasbitung.

\section{Hasil dan Pembahasan}

Berdasarkan hasil perolehan dan pengolahan data yang diuji melalui analisis statistik dapat diperoleh bahwa model pembelajaran Process Oriented Guided Inquiry Learning pada materi bangun ruang sisi datar dapat memberikan hasil yang maksimal pada kemampuan analogi matematis peserta didik. Dari hasil tes kemampuan analogi matematis yang dilaksanakan, dapat dilihat perbedaan kemampuan analogi matematis peserta didik kelas eksperimen lebih baik dari pada kelas kontrol. Hasil perhitungan data skor kemampuan analogi matematis peserta didik terhadap kelas eksperimen dan kelas kontrol pada materi bangun ruang sisi datar, diperoleh data sebagai berikut:

Tabel 1. Skor Kemampuan Analogi Matematis Peserta Didik Kelas Eksperimen dan Kelas Kontrol

\begin{tabular}{|c|c|c|c|c|c|c|}
\hline Kelas & $Y_{\text {min }}$ & $Y_{\text {maks }}$ & Skor Ideal & $\overline{\boldsymbol{Y}}$ & $s$ & $s^{2}$ \\
\hline Eksperimen & 53 & 96 & \multirow{2}{*}{96} & 76,5161 & 12,2743 & 150,6581 \\
\hline Kontrol & 51 & 96 & & 71,1250 & 11,5696 & 133,8548 \\
\hline
\end{tabular}

Berdasarkan data pada Tabel 1 menunjukan bahwa rata-rata skor kemampuan analogi matematis peserta didik kelas eksperimen lebih tinggi dibandingkan dengan kelas kontrol. Skor maksimum yang diperoleh kelas eksperimen dan kelas kontrol sama yaitu 96, sedangkan untuk skor terendah kelas eksperimen yaitu 53 dengan mencapai rata-rata skor 76,5161 dan kelas kontrol yaitu 51 dengan mencapai rata-rata skor 71,1250 dari skor ideal yaitu 96. Selain mengukur rata-rata keseluruhan peneliti juga mengukur tingkat persentase setiap indikator. Berikut ini adalah persentase indikator butir soal kemampuan analogi matematis peserta didik kelas eksperimen dan kelas kontrol: 
Tabel 2. Persentase Indikator Kemampuan Analogi Matematis

\begin{tabular}{|c|c|c|c|c|}
\hline \multirow[b]{2}{*}{ No. } & \multirow{2}{*}{$\begin{array}{c}\text { Indikator Kemampuan } \\
\text { Analogi Matematis }\end{array}$} & \multirow{2}{*}{$\begin{array}{l}\text { Nomor } \\
\text { Soal }\end{array}$} & \multicolumn{2}{|c|}{ Persentase Skor } \\
\hline & & & $\begin{array}{c}\text { Kelas } \\
\text { Eksperimen }\end{array}$ & $\begin{array}{c}\text { Kelas } \\
\text { Kontrol }\end{array}$ \\
\hline \multirow{2}{*}{1.} & \multirow{2}{*}{$\begin{array}{l}\text { Mencari keserupaan proses } \\
\text { dalam tugas matematika tanpa } \\
\text { perhitungan }\end{array}$} & 1 & $81,18 \%$ & $75,26 \%$ \\
\hline & & 2 & $79,84 \%$ & $71,35 \%$ \\
\hline \multirow{2}{*}{2.} & \multirow{2}{*}{$\begin{array}{l}\text { Mengindentifikasi keserupaan } \\
\text { proses yang terjadi antara } \\
\text { beberapa materi matematika } \\
\text { dalam pokok bahasan sama }\end{array}$} & 3 & $58,87 \%$ & $46,88 \%$ \\
\hline & & 4 & $93,55 \%$ & $92,97 \%$ \\
\hline \multirow{2}{*}{3.} & \multirow{2}{*}{$\begin{array}{l}\text { Mengidentifikasi keserupaan } \\
\text { proses yang terjadi antara } \\
\text { beberapa materi matematika } \\
\text { dalam pokok bahasan berbeda }\end{array}$} & 5 & $77,42 \%$ & $68,75 \%$ \\
\hline & & 6 & $82,26 \%$ & $81,25 \%$ \\
\hline \multirow{2}{*}{4.} & \multirow{2}{*}{$\begin{array}{l}\text { Mencari keserupaan proses } \\
\text { antara materi matematika jika } \\
\text { dikaitkan dengan kehidupan } \\
\text { sehari-hari }\end{array}$} & 7 & $76,61 \%$ & $75,78 \%$ \\
\hline & & 8 & $87,90 \%$ & $80,47 \%$ \\
\hline
\end{tabular}

Berdasarkan data pada Tabel 2 terlihat bahwa persentase indikator mencari keserupaan dalam tugas matematika tanpa perhitungan yang termuat dalam soal nomor 1 sebesar 81,18\% untuk kelas eksperimen dan 75,26\% untuk kelas kontrol dan untuk soal nomor 2 sebesar 79,84\% untuk kelas eksperimen dan $71,35 \%$ untuk kelas kontrol. persentase indikator mengidentifikasi keserupaan proses yang terjadi antara beberapa materi matematika dalam pokok bahasan sama yang termuat dalam soal nomor 3 sebesar 58,87\% untuk kelas eksperimen dan 46,88\% untuk kelas kontrol dan untuk soal nomor 4 sebesar 93,55\% untuk kelas eksperimen dan 92,97\% untuk kelas kontrol. persentase indikator mengidentifikasi keserupaan proses yang terjadi antara beberapa materi matematika dalam pokok bahasan berbeda yang termuat dalam soal nomor 5 sebesar 77,42\% untuk kelas eksperimen dan 68,75\% untuk kelas kontrol dan untuk soal nomor 6 sebesar $82,26 \%$ untuk kelas eksperimen dan $81,25 \%$ untuk kelas kontrol. persentase indikator mencari keserupaan proses antara materi matematika jika dikaitkan dengan kehidupan sehari-hari yang termuat dalam soal nomor 7 sebesar 76,61\% untuk kelas eksperimen dan 75,78\% untuk kelas kontrol dan untuk soal nomor 8 sebesar $87,90 \%$ untuk kelas eksperimen dan $80,47 \%$ untuk kelas kontrol. 


\section{Simpulan}

Berdasarkan pembahasan hasil penelitian dapat disimpulkan bahwa skor kemampuan analogi matematis peserta didik yang diajarkan dengan menggunakan model pembelajaran Process Oriented Guided Inquiry Learning memiliki rerata 76,5161 dengan simpangan baku 12,2743 sedangkan skor kemampuan analogi matematis peserta didik yang tidak diajarkan dengan model pembelajaran Process Oriented Guided Inquiry Learning memiliki rerata 71,1250 dengan simpangan baku 11,5696. Hal ini menandakan bahwa dalam penelitian ini rerata skor kemampuan analogi matematis peserta didik yang diajarkan dengan menggunakan model Process Oriented Guided Inquiry Learning lebih baik dibandingkan dengan rerata skor kemampuan analogi matematis peserta didik yang tidak diajarkan dengan menggunakan model pembelajaran Process Oriented Guided Inquiry Learning. Hasil pengujian hipotesis menggunakan uji-t pada penelitian ini diperoleh hasil $t_{\text {hitung }}=$ $1,7945>1,6702=t_{\text {tabel }}$. menunjukkan bahwa terdapat perbedaan hasil kemampuan analogi matematis peserta didik antara kelas eksperimen dan kelas kontrol sehingga dapat disimpulkan bahwa model pembelajaran Process Oriented Guided Inquiry Learning berpengaruh terhadap kemampuan analogi matematis siswa. Pengaruh model tersebut diklasifikasikan dengan Effect Size diperoleh sebesar 0,4660. Penelitian ini dapat disimpulkan bahwa terdapat pengaruh model pembelajaran Process Oriented Guided Inquiry Learning terhadap kemampuan analogi matematis peserta didik di SMP Negeri 2 Rangkasbitung dengan kriteria sedang.

\section{Daftar Pustaka}

Azmi, M. P. (2017). Mengembangkan Kemampuan Analogi Matematis. Journal Cendekia: Jurnal Pendidikan Matematika Volume 1, Nomor 1, 100111.

Fitriani, W. (2017). Perbandingan Model Pembelajaran Process Oriented Guided Inquiry Learning (POGIL) dan Guided Inquiry (GI) Terhadap Keterampilan Berpikir Kritis Siswa. Jakarta: Fakultas Ilmu Tarbiyah dan Keguruan Universitas Islam Negeri Syarif Hidayatullah. 
Hendriana, H., Rohaeti, E. E., \& Sumarmo, U. (2017). Hard Skills dan Soft Skills Matematik Siswa. Bandung: PT Refika Aditama.

Lestari, K. E., \& Yudhanegara, M. R. (2015). Penelitian Pendidikan Matematika. Bandung: PT Refika Aditama.

Rahman, R., \& Maarif, S. (2014). Pengaruh Penggunaan Metode Discovery Terhadap Kemampuan Analogi Matematis Siswa SMK Al-Ikhsan Pamarican Kabupaten Ciamis Jawa Barat. Jurnal Infinity: Jurnal Ilmiah Program Studi Matematika STKIP Siliwangi Bandung Vol 3, No.1,, 33-58.

Rahmawati, D. I., \& Pala, R. H. (2017). Kemampuan Penalaran Analogi dalam Pembelajaran Matematika. Jurnal Euclid: Prodi Pendidikan Matematika Unswagati Cirebon Volume 4, Nomor 2, 717-725.

Rosidah. (2013). Keefektifan Pembelajaran POGIL Berbantuan LKPD Terhadap Kemampuan Pemecahan Masalah Materi Pokok Peluang. Jurnal Kreano: Jurusan Matematika FMIPA UNNES Volume 4, Nomor 1, 73-79.

Sugiyono. (2014). Metode Penelitian Kombinasi (Mixed Methods). Bandung: Alfabeta.

Sumarmo, U. (2014). Asesmen Soft Skill dan Hard Skill Matematik Siswa dalam Kurikulum 2013. Makalah Seminar Pendidikan Matematika Sekolah Tinggi Agama Islam Negeri Batusangkar, 1-30.

Widyaningsih, S. Y., Haryono, \& Saputro, S. (2012). Model MFI dan POGIL Ditinjau dari Aktivitas Belajar dan Kreativitas Siswa Terhadap Prestasi Belajar. Jurnal Inkuiri: Jurnal Pascasarjana UNS Volume 1, Nomor 3, 266-275.

Zaenal, R. M. (2017). Pengarauh Model Pembelajaran POGIL Terhadap Kemampuan Pemecahan Masalah Matematik dan Self Efficacy Ditinjau dari Kemampuan Awal Matematika Siswa di SMPN Jakarta Utara. Jakarta: Fakultas Matematika dan Ilmu Pengetahuan Alam Pascasarjana Universitas Negeri Jakarta. 